\title{
The Ottone-Levanto Line of Eastern Liguria (Italy) uncovered: a Late Eocene-Early Oligocene snapshot of Northern Apennine geodynamics at the Alps/Apennines Junction
}

\author{
${ }^{1}$ Dipartimento di Scienze della Terra, Università di Pisa, Via S. Maria, 53, 56126 Pisa, Italy; *Corresponding author, E-mail: francesca.menegh- \\ ini@unipi.it \\ ${ }^{2}$ Istituto di Geoscienze e Georisorse, C.N.R. Consiglio Nazionale delle Ricerche, Via Moruzzi 1, 56124 Pisa, Italy
}

(Received: July 10, 2018; Revised accepted: May 1, 2019)

https://doi.org/10.18814/epiiugs/2019/019009

The Northern Apennine orogenic belt developed during subduction and collision between the Europe and Adria plates. The northernnmost sector of the nappe pile is dissected by several tectonic lines, whose kinematics and age are crucial for the understanding of the Northern Apennine evolution, and its mutual relationships with the neighbouring Alps. Between these, the Ottone-Levanto line still lacks an unambiguous geodynamic interpretation, because of lacking of well-exposed outcrops. We describe unique fault rocks exposures representative of the Ottone-Levanto line whose structural features indicate deformation with components of contraction through top-to-the-NE thrusting and contemporaneous top-tothe-SW sinistral/dip-slip shearing. The collected data coupled with regional and map-scale evidences indicate that the Ottone-Levanto line acted as a sinistral transpressional shear zone during the Late Eocene-Early Oligocene. Placing our data in the regional context allows correlating the Ottone-Levanto line with surrounding lines dissecting the Alpine-Apennine junction. We propose that the Ottone-Levanto developed in a conjugate system during collision and northward displacement of the Adria plate, resulting in east-and westward thrusting of the Alpine-Apennines orogenic core.

\section{Introduction}

The Northern Apennine collisional belt records the long-lived tectonic history of convergence between the Europe and Adria plates, active since Late Cretaceous. The Liguria Region exposes the junction between the Alps and Northern Apennine orogenic belts (e.g. Elter and Pertusati, 1973, Molli et al., 2010) and is therefore a key-area for the reconstruction of the geodynamic evolution of the Northern Apennines belt in the wider context of the Mediterranean area. The Ligurian Units of the Northern Apennines are, in fact, characterized by a complex tectonic evolution derived from the interference, in space and time, of predominantly west- ("Alpine”) and east-verging ("Apennine") deformations. Several studies of various Mediterranean orogens have shown that neighbouring orogens with different subduction polarities are typically characterized by arcuate mountain chains affected by large-scale rotations and by displacements along the orogenic strike (Faccenna et al., 2004). Similarly, the northernmost sector of the Northern Apennine is a complex, curved fold-and-thrust belt dissected by several high-angle tectonic discontinuities of regional importance, trending both parallel and orthogonal to the mean strike of the main thrust surfaces (Marroni and Treves, 1998; Cerrina Feroni et al., 2004).

The Ottone-Levanto line (hereafter OLL) (Fig.1) is a parallel-trending discontinuity first defined as the boundary between the Internal and External Ligurian Units of the Northern Apennine: these groups of units make up the top of the Northern Apennine stack and crop out east of the Sestri-Voltaggio line, traditionally considered as the "tectonic boundary" between the Northern Apennines and the Ligurian Alps. Both the Ligurian Alps and the Ligurian Units record "Alpine" as well as "Apennine" deformations (Elter and Pertusati, 1973; Molli et al., 2010; Marroni et al., 2017). Since his first description by Elter and Pertusati, (1973), several interpretations have been proposed for this fault zone, with differences mainly concerning age, kinematics and geodynamic role played by this shear zone. The reason for these often contrasting views is the lacking of well-exposed outcrops of the fault zone. No matter tens of years of intense geological mapping, and a coverage of the Northern Apennine at the 1:10.000 scale, most of the interpretations rely on geological mapping and map scale reconstructions, but the literature still lacks studies of good fault zone outcrops, with analyses of fault rocks, deformation mechanisms, unambiguous definition of the kinematic indicators, or evidence of relative chronology between shear zone activity and regional evolution of the area.

In this paper we report on a unique, well-exposed section of the boundary between the Internal and External Units identified for the first time during a recent field survey in the Sturla valley, located in the Liguria region. After an overview on the Ligurian Units, and the 
controversies on their geodynamic interpretation, we review the state of the art regarding this tectonic line, so to introduce the tectonic importance of the OLL in the wider Northern Apennine picture. We then describe the characteristics of the fault rocks marking the OLL, the structure and geometry of the fault zone at map scale, and we place these data in the regional context of the northernmost sector of the Apennine belt, discussing a possible geodynamic picture of the evolution of the Alps/Apennines junction area during the Late Eocene-Oligocene time.

\section{Tectonic and Structural Overview of the North- ern Apennine in Liguria}

The Northern Apennine collisional belt (Fig. 1) originated by the Late Cretaceous-Middle Eocene closure of the western arm of the Tethyan ocean (i.e. the Ligure-Piemontese basin), and the Late EoceneEarly Oligocene continental collision of the Adria microplate with the European plate (Marroni et al., 2017 and quoted references). From

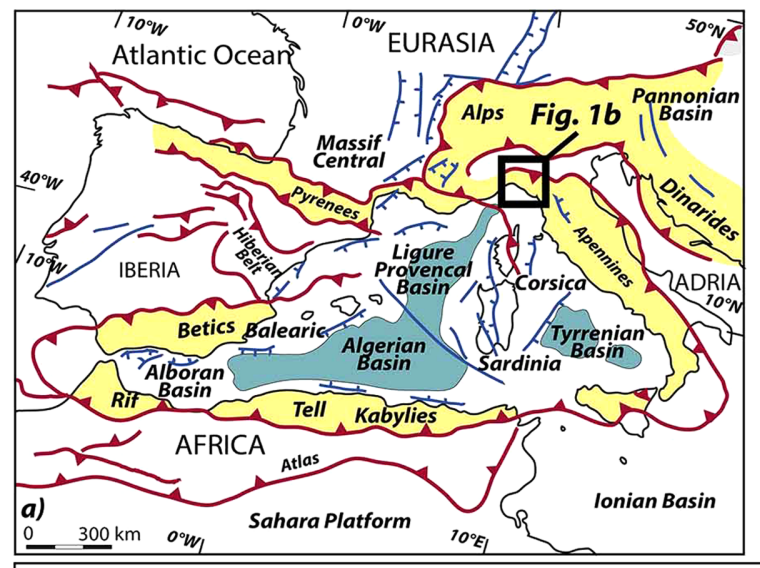

b)

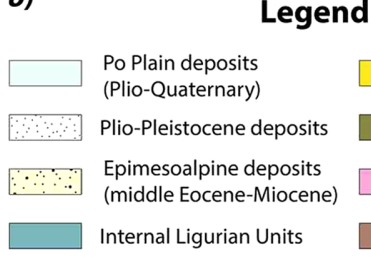

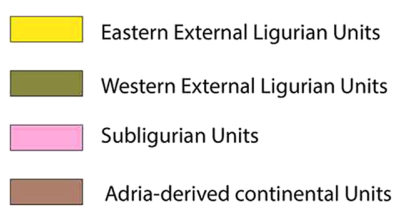
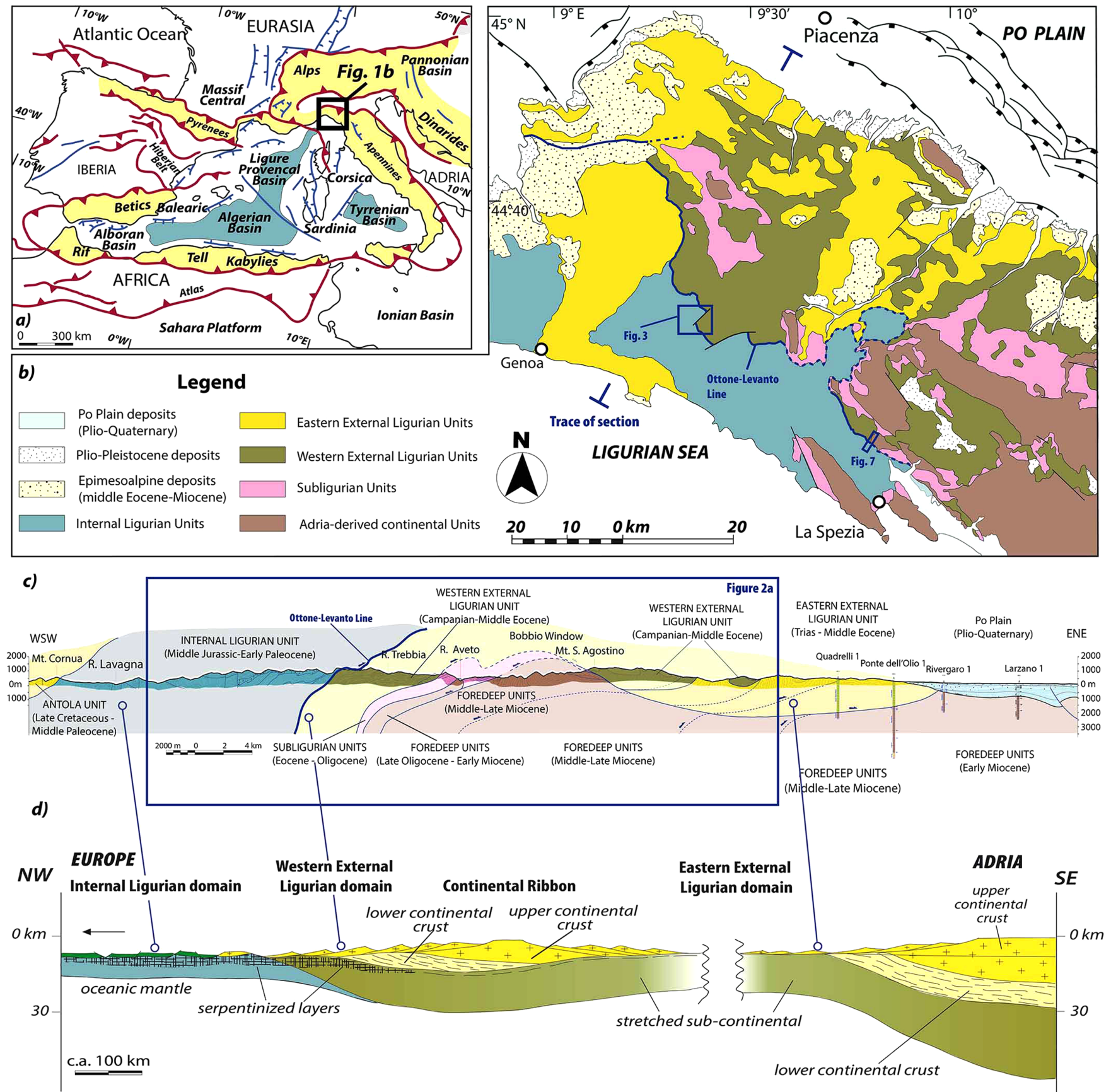

Figure 1. General geology of the Northern Appenines. a) Simplified scheme of the circum-Mediterranean collisional belts; b) Tectonic map of the Emilian-Ligurian sector of the Northern Apennines. The OLL and VVL are indicated (dashed when inferred/reworked), as well as the location of the mapped area (Fig. 3); c) Regional cross section through the Emilian-Ligurian Northern Apennines; d) paleogeographic reconstruction of the Ligure-Piemontese oceanic basin and its transition to the Adria continental margin, and inferred paleogeographic position of the units of Fig. $1 c$. 
Early Oligocene onward, the retreat of the subduction slab produced a progressive migration of the deformation toward the eastern domains of the Adria plate, associated with coeval extension in the western side of the Apennine (Faccenna et al., 2004). There is now a general consensus on a belt evolution through two, diachronous oppositelydipping subductions: a Late Cretaceous-Middle Eocene east-dipping "Alpine" subduction, and a Late Eocene-present west-dipping "Apennine" subduction (e.g. Elter and Pertusati, 1973; Doglioni, 1991; Molli et al., 2010; Marroni et al., 2017). The result is a fold-and-thrust belt of E- to NE-verging structural units, with the Ligurian Units at the top of the tectonic pile, thrust over the Subligurian and Tuscan Units (Fig. 1).

The Ligurian Units are the only units recording the west-verging "Alpine" deformations, and are extensively exposed in the Liguria Region, at the northwestern sector of the Northern Apennine (Fig. 1). They are considered as the remnants of the Ligure-Piemontese oceanic basin, formed since Middle Jurassic between the Adria and Europe plate margins (Marroni and Pandolfi, 2007), and its transition to the Adria continental margin (Fig. 2, e.g. Molli et al., 2010; Marroni et al., 2017). In particular, Internal (IL) and External Ligurian Units (EL) are classically distinguished, representative of two neighbouring paleogeographic domains (Figs 1, 2; Treves 1984; Marroni and Pandolfi, 2007).

The IL (Fig. 2; Marroni and Pandolfi, 2007) comprise a Jurassic ophiolite sequence, a Middle Jurassic to Santonian hemipelagic cover, a Santonian to Early Paleocene siliciclastic and carbonate turbidite complex and Early Paleocene debris flow and slide deposits. The IL are affected by a pre-Oligocene deformation history (Fig. 2) achieved during progressive phases of dewatering and underthrusting, underplating (D1), and later exhumation (D2) in a subduction zone characterized by an accretionary prism setting with high sedimentary input (Marroni et al., 2004; Meneghini et al., 2009). Associated with D1 deformation is an HP/LT metamorphism ranging from very low-grade to the low blueschists facies (e.g. Leoni et al., 1996). Even if no geochronological data are available, the HP/LT metamorphism in the IL Units can be regarded as Early to Late Eocene in age by correlation with the HP oceanic units from Voltri Group (49 to 33 MA; Federico et al., 2005), located just $30 \mathrm{~km}$ west of the study area. The occurrence of a subduction zone is suggested also by the finding of pebbles of andesites in the Early Oligocene conglomerates from Subligurian Units (Aveto Fm.; Elter et al., 1999). These andesites are interpreted as the remnants of a volcanic arc (e.g. Malusà et al. 2015) resulting from a subduction where the IL Units were involved since Late Paleocene. D1-related west-verging thrusts represent the boundaries between the main IL units, responsible for their emplacement and internal imbrication (Marroni and Pandolfi, 1996; Crispini and Capponi, 2001; Meneghini et al., 2009). Synorogenic wedge extension followed accretion-related deformation, and developed through parallel folds and low-to high-angle normal faults, resulting in the exhumation of the IL up to the surfaces (Fig. 2). Deformation in the accretionary wedge is bracketed between Early Paleocene (age of youngest deposits involved in D1) and before the Early Oligocene (Fig. 2), when the IL sedimentary succession became one of the source areas of the Val Borbera Conglomerate of the Tertiary Piedmont basin (Di Biase et al., 1997).

More complex, and highly debated, is the configuration of the EL (Fig. 2), for which Marroni et al., (2001) proposed a derivation from an ocean-continent transition zone toward the Adria continental margin. In this configuration, they defined western EL, belonging to the ocean-ward ocean-continent transition, and eastern EL, located at the thinned edge of the Adria continental margin, separated by an extensional allochton (Fig. 2, see Marroni et al., 2017). The western EL successions features Santonian-Early Campanian sedimentary mélanges at their base, characterized by the close association of fragments of continental mantle as well as of lower and upper continental crust (e.g. Saccani et al., 2015). Differently, the base of the eastern EL successions lacks any mafic and ultramafic component and it typically includes Early to Late Cretaceous pelagic, carbonate and siliciclastic deposits. The most representative unit to the eastern EL successions, the Cassio Unit, shows slices of a Middle Triassic carbonate platform at the base of the pelagics, allowing Marroni et al. (2001) to propose an original continental substratum for this succession, i.e. the westernmost thinned edge of the Adria plate. The basal successions of both groups of units are all covered by Late CampanianMaastrichtian carbonate turbidites of the Helminthoid Flysch, and Paleocene-uppermost Middle Eocene mixed siliciclastic-carbonate turbidites (Fig. 2).

Both the eastern and western successions of EL are characterized by a pre-Oligocene polyphase deformation history, developed under shallow diagenetic conditions and responsible for the actual structural edifice (Fig. 2): the sedimentary mélange of the western EL features a polyphase deformation history that includes several phases of folding and thrusting (Fig. 2) that some authors have interpreted as acquired in a basin located at the rear of the Northern Apennines double-vergent accretionary prism as consequence of an east-dipping subduction (Molli et al., 2010, Marroni et al., 2017). Alternative interpretation depicts this structural evolution as due to frontal accretion on a wedge connected to a west-dipping subduction zone (Treves, 1984).

As for the IL, the structures in the EL are all sealed by the deposits of the Epiligurian basin (uppermost Middle Eocene to Tortonian), thus dating these deformations to the pre-Middle Eocene (Fig. 1).

\section{Previous Interpretations of the Ottone-Levanto Line: a Review}

The important role of the OLL in the tectonic evolution of the Northern Apennine has been invoked since its first definition, so that it has been the focus of several contributions since the 70 s providing profoundly different interpretations of its tectonic role. The trace of fault itself has been drawn differently through time, and for the sake of clarity, most authors have preferred to stick with the "original" name used to define the shear zone, instead of introducing new names.

Elter and Pertusati (1973) firstly defined the OLL as a discontinuity separating the IL, from the EL. They interpreted this line to be the southern prolongation of the so-called Villalvernia-Varzi line (VVL), i.e. as a thrust active in the Middle to Late Miocene leading the emplacement of the pre-Oligocene, mesoalpine nappe stack over the Adria margin.

More than 15 years later, Laubscher et al., (1992) interpreted the OLL as post-Aquitanian superficial high-angle splay of the low-angle thrust. In contrast, Elter and Marroni (1991) and Marroni and Treves 

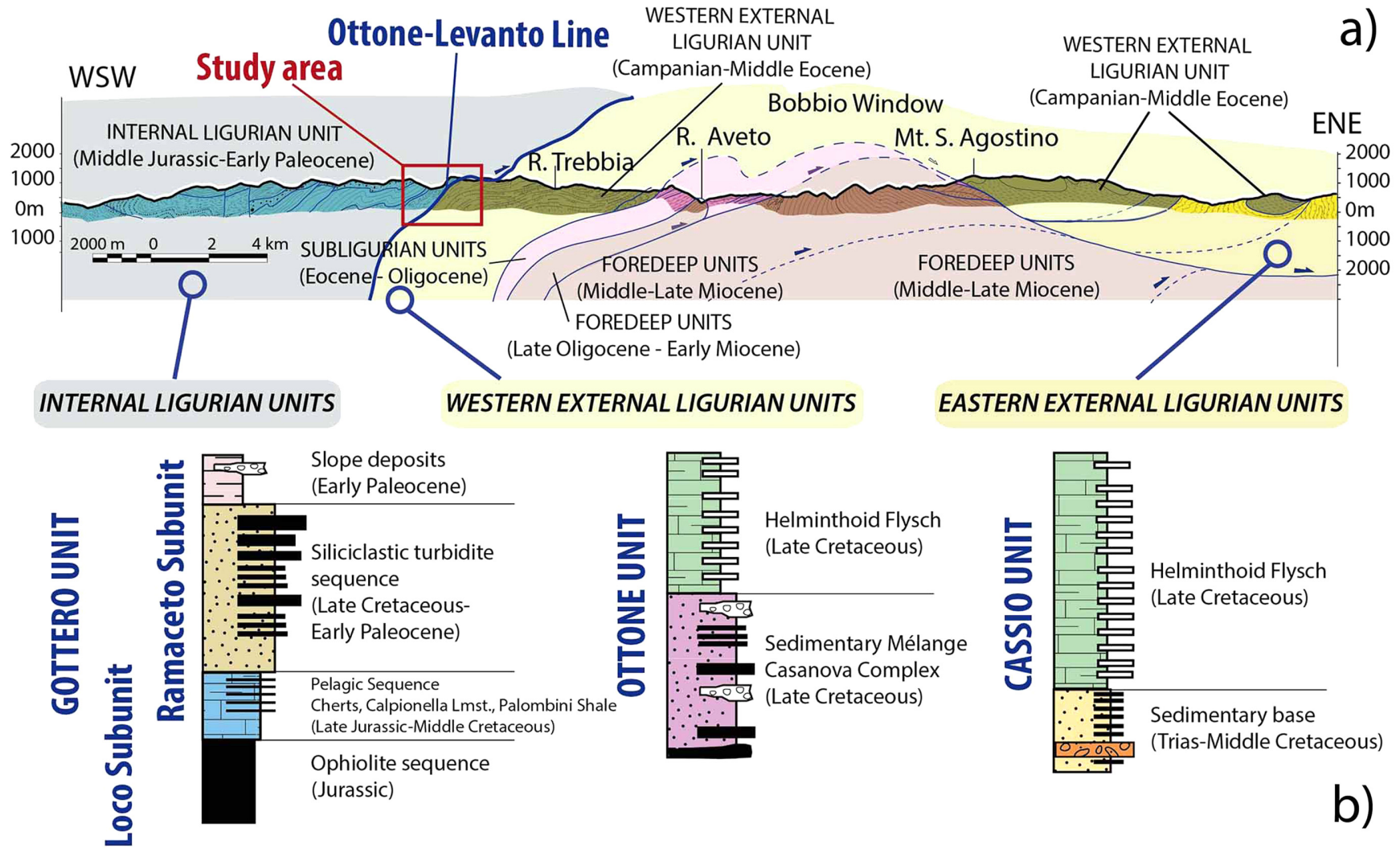

INTERNAL LIGURIAN UNITS

\begin{tabular}{|c|c|c|c|}
\hline $\begin{array}{c}\text { DEFORMATION } \\
\text { PHASE }\end{array}$ & $\begin{array}{l}\text { DISTINCTIVE } \\
\text { STRUCTURES }\end{array}$ & \begin{tabular}{|c|} 
GEODYNAMIC \\
INTERPRETATION
\end{tabular} & RELATIVE TIMING \\
\hline \multirow{3}{*}{ D1 } & D1a: veining & $\begin{array}{l}\text { UNDERTHRUSTING } \\
\text { ( } \mathrm{w} / \text { dewatering } \\
\text { and compaction) }\end{array}$ & \multirow{4}{*}{$\begin{array}{c}\text { EARLY PALEOCENE } \\
\text { (youngest deposits involved in deformation) }\end{array}$} \\
\hline & $\begin{array}{l}\text { D1b: isoclinal, } \\
\text { similar folds, west- } \\
\text { verging, slaty } \\
\text { cleavage under } \\
\text { very low- to } \\
\text { blueschist facies } \\
\text { metamorphism }\end{array}$ & \multirow[t]{2}{*}{$\begin{array}{l}\text { SHALLOW-LEVEL } \\
\text { UNDERPLATING TO } \\
\text { ACCRETIONARY } \\
\text { WEDGE }\end{array}$} & \\
\hline & $\begin{array}{l}\text { Dic: thrusting, } \\
\text { west-vergence, } \\
\text { foliated } \\
\text { cataclasites }\end{array}$ & & \\
\hline \multirow[t]{2}{*}{ D2 } & $\begin{array}{l}\text { D2a: paralle folds, } \\
\text { sub-horizontal } \\
\text { axial plane, east- } \\
\text { verging, w/ low- } \\
\text { angle normal }\end{array}$ & \multirow{2}{*}{$\begin{array}{l}\text { WEDGE } \\
\text { EXTENSION, } \\
\text { EXHUMATION }\end{array}$} & \\
\hline & $\begin{array}{l}\text { D2b: high angle } \\
\text { normal faulting }\end{array}$ & & $\begin{array}{c}\text { EARLY OLIGOCENE } \\
\text { age of BTP conglomerates } \\
\text { (showing D1- and D2-deformed pebbles) }\end{array}$ \\
\hline D3 & $\begin{array}{c}\text { open, gentle folds, } \\
\text { high- to low-angle } \\
\text { axial plane, } \\
\text { disjunctive } \\
\text { cleavage }\end{array}$ & $\begin{array}{l}\text { POST-OROGENIC } \\
\text { DEFORMATION }\end{array}$ & \\
\hline
\end{tabular}

EXTERNAL LIGURIAN UNITS

\begin{tabular}{|c|c|c|c|}
\hline $\begin{array}{c}\text { DEFORMATION } \\
\text { PHASE }\end{array}$ & $\begin{array}{l}\text { DISTINCTIVE } \\
\text { STRUCTURES }\end{array}$ & \begin{tabular}{|l} 
GEODYNAMIC \\
INTERPRETATION
\end{tabular} & RELATIVE TIMING \\
\hline \multirow{2}{*}{ D1 } & $\begin{array}{c}\text { D1a: close to sub- } \\
\text { isoclinal, similar } \\
\text { folds, west-verging, } \\
\text { disjunctive } \\
\text { cleavage }\end{array}$ & \multirow{2}{*}{$\begin{array}{l}\text { ACCRETIONTO } \\
\text { OROGENIC WEDGE }\end{array}$} & \multirow[t]{2}{*}{$\begin{array}{l}\text { LOWERMOST MIDDLE EOCENE (youngest deposits } \\
\text { involved in deformation) }\end{array}$} \\
\hline & $\begin{array}{c}\text { Dest-vergence, } \\
\text { foliated } \\
\text { cataclasites }\end{array}$ & & \\
\hline \multirow[t]{2}{*}{ D2 } & \begin{tabular}{|c|} 
D2a: open parallel \\
folds, sub- \\
horizontal axial \\
plane, east- \\
verging, w/ low- \\
angle normal \\
faulting
\end{tabular} & \multirow[t]{2}{*}{$\begin{array}{c}\text { SYNOROGENIC } \\
\text { WEDGE } \\
\text { EXTENSION, } \\
\text { EXHUMATION }\end{array}$} & PRE-OLIGOCENE \\
\hline & $\begin{array}{l}\text { D2b: high angle } \\
\text { normal faulting }\end{array}$ & & UPPERMOST MIDDLE EOCENE (age of Ranzano deposits) \\
\hline D3 & 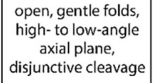 & \begin{tabular}{|l} 
POST-OROGENIC \\
DEFORMATION
\end{tabular} & \\
\hline
\end{tabular}

Figure 2. a) Close-up of Fig.1c showing the structural relationship among Ligurian units; b) simplified stratigraphic columns of the Ligurian units reconstructed successions; c) Synoptic schemes summarizing the main features of the deformation phases recognized in the IL and EL Units, their proposed geodynamic interpretation, and their inferred relative timing.

(1998) proposed for the OLL the role of a sinistral transpressional fault that accommodated the northward translation of the Adria plate in the pre-Oligocene time. Therefore, these authors envisaged the OLL as a "fossil" structural element active before the Oligocene.

Subsequently, Castellarin (2001) re-proposed the interpretation of the OLL as a middle Miocene thrust that re-activated an older line. Differently, Cerrina Feroni et al., (2004) proposed for the OLL a dex- tral strike-slip kinematics and a not older than Langhian age. In contrast, Mosca et al., (2010) proposed a Late Eocene-Early Oligocene origin of the OLL during the compressional events connected with the Periadriatic fault. More recently, Malavieille et al., (2016) have proposed for the OLL an older origin, in the Late Cretaceous, as a backthrust along the retroside of the Alpine wedge, associated with eastward dipping subduction. 


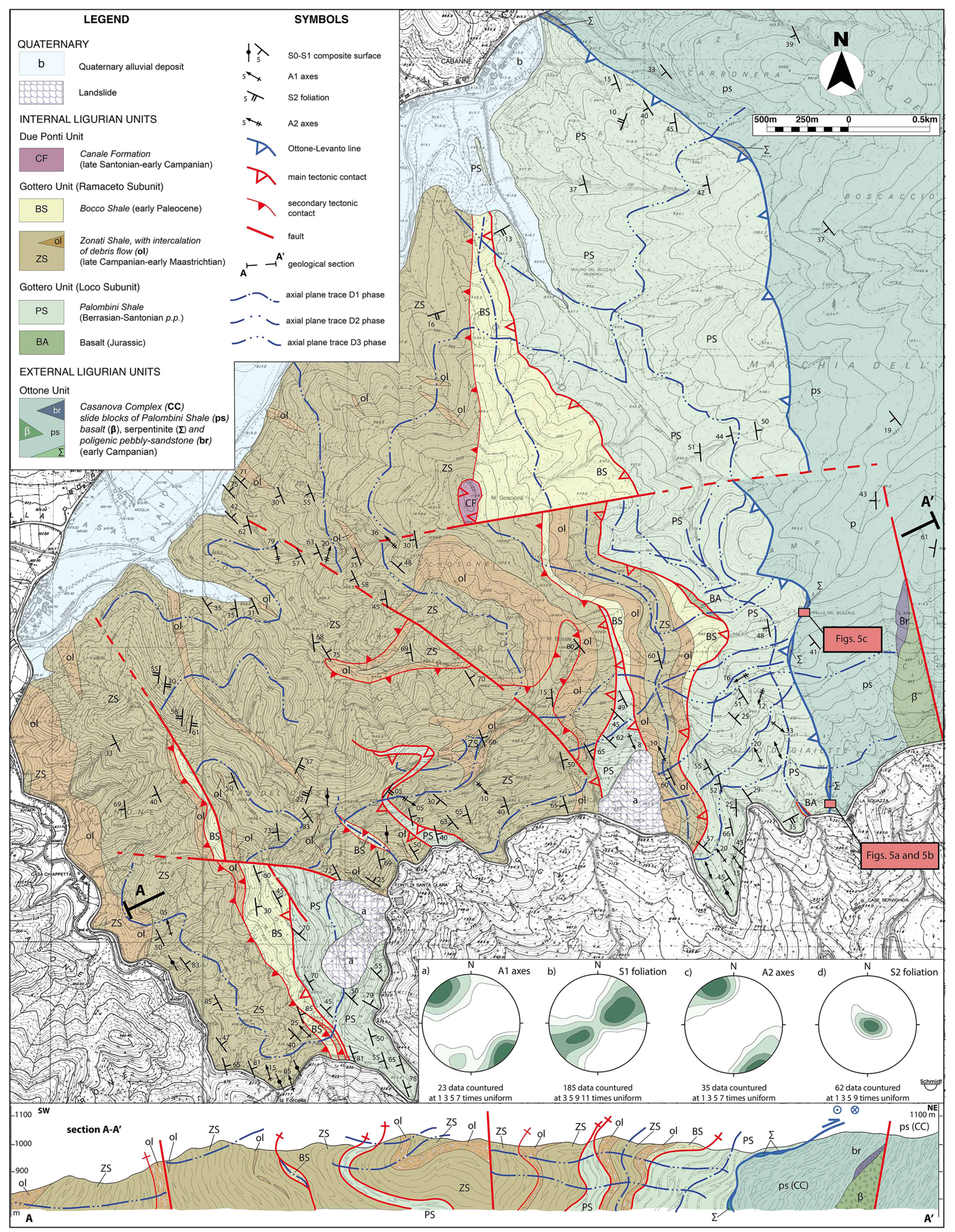

Figure 3. Geological-structural map and cross section at same scale of the high Sturla Valley. The attitude of the axial planes of the main folding phases are shown. In the inset, the contour diagrams of equal-area, lower hemisphere stereographic projections summarize the orientation of the main structural elements in the study area. Red boxes show location of images in Fig. 5. 


\section{Map Scale Architecture of the Ligurian Units in the High Sturla Valley}

During a recent field survey in the valley of the Sturla river (Liguria Region, ca. $60 \mathrm{~km}$ east of the town of Genova, Figs. 1 and 3), we detected several well-exposed outcrops of a mappable fault rock structurally juxtaposed between along IL and EL, and therefore referable to the OLL (Fig. 3).

West of the OLL is an imbricate stack of thrust sheets (Fig. 3) belonging to the IL Gottero Unit and mapped as Ramaceto and Loco subunits (Elter et al., 2010). The Ramaceto subunit consists of basin plain thin-bedded turbidites (Zonati Shale), unconformably topped by the mass-gravity deposits (Bocco Shale). The Loco subunit is represented predominantly by the hemipelagic deposits (Palombini Shale) and scattered basalts (Figs. 2, 3).

The Ramaceto/Loco subunits boundary (Figs. 2 and 3), is marked by cataclastic shear zones deformed by D2 folds. After removing the effect of the D2 deformation using the techniques described in Masini et al., (2010), these shear zones show west-vergence and can be ascribed to the underplating of the unit to the accretionary prism (D1c,
Fig. 2), according to elsewhere in the IL (Marroni and Pandolfi, 1996, Marroni et al., 2004). Typical for the IL (Meneghini et al., 2009) is also the repetition of several thrust sheets for each subunit, as a result of progressive deformation during the D1 phase (Fig. 3): each thrust sheet, is also internally deformed by D1b isoclinal folding with penetrative scaly cleavage (Fig. 3). The most evident structures in field are the asymmetric, parallel folds of the D2a sub-phase (Figs. 2, 3) deforming both the axial planes of the folds and the shear zones of the D1, as visible in the cross-section of Fig. 3. The D2a folds are characterized by eastward vergence; their axial planes appear now deformed by the D3 open folds with low-angle axial planes (Figs. 2, 3).

East of the OLL crops out the Ottone Unit (Figs. 2, 3), belonging to the western EL and represented here solely by an Early Campanian sedimentary mélange (Marroni et al., 2001), known as Casanova Complex (CC). It consists here of huge slide blocks of Palombini Shale, basalt, peridotite, granite and gabbro, enclosed in a matrix of pebbly mudstone and pebbly sandstones (Elter et al., 1991). The mélange is deformed under anchizone-diagenesis conditions, with the most easily recognizable structures at field-scale being D2-phase east-verging, close to open large-scale folds with subhorizontal axial planes and axes roughly trending NW-SE. No map scale structures of this phase

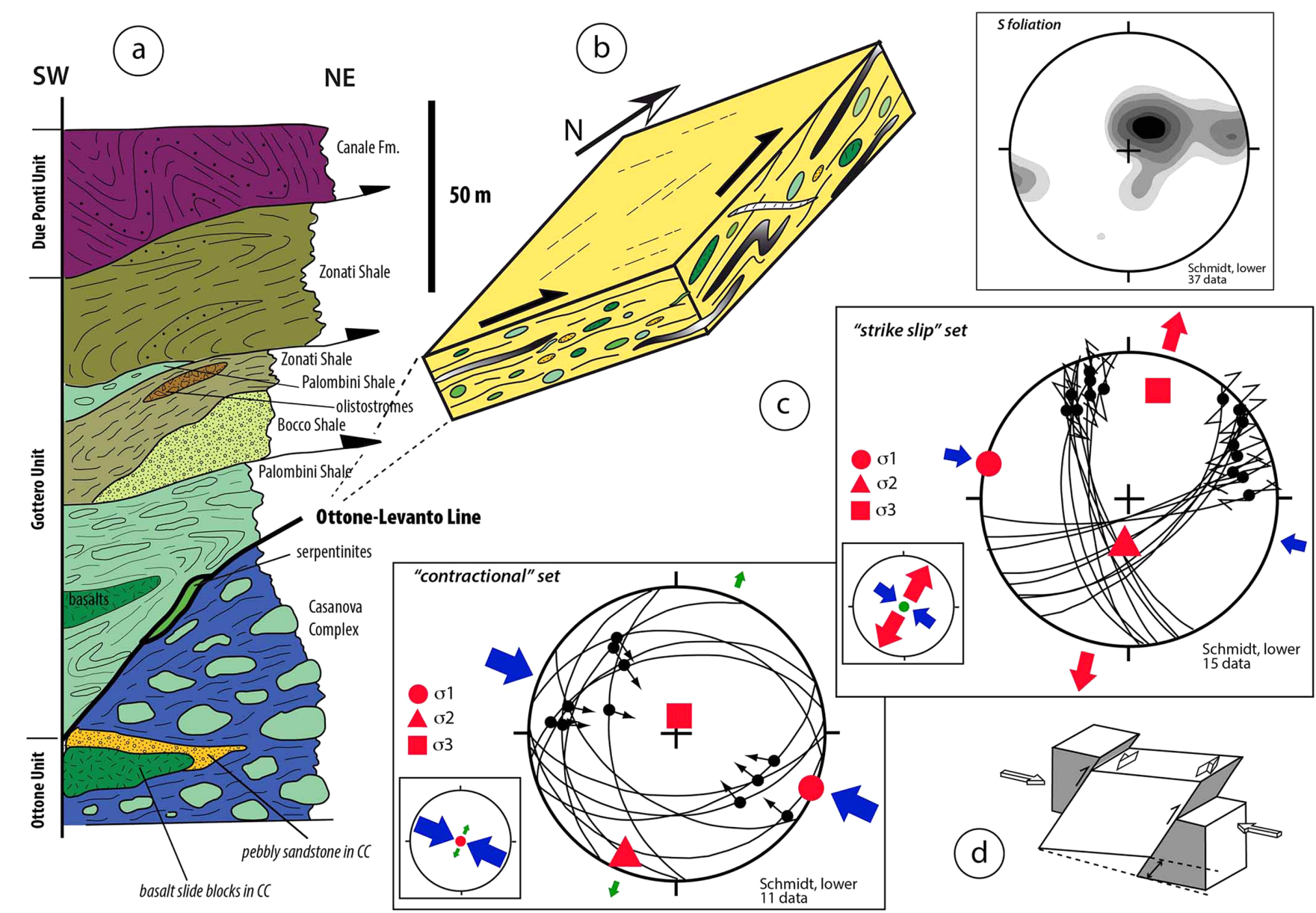

Figure 4. Structural data of the cataclasite marking the OLL. a) Schematic log across the OL-line fault trace showing the relationships of the cataclasite with the adjacent units; b) block diagram representation of the cataclasite fabric; c) equal-area, lower hemisphere stereographic projections of foliation planes (upper stereonet) and foliation surfaces-striae pairs (in the two lower stereonets). The two main sets of foliation-striae pairs have been plotted in separate stereonets, also showing the interpreted, associated stress field (WinTensor software, Delvaux and Sperner, 2003): a "contractional" and a strike slip stress field can be reconstructed for the two sets; d) schematic representation of an inclined transpression, modified after Jones et al., (2004). 
have been identified in the study area (Fig. 3).

The Loco subunit is juxtaposed over the sedimentary mélange of the Ottone Unit through a meter-scale thick shear zone, a well-exposed candidate of the OLL (Fig. 3).

\section{The Ottone-Levanto Line: Geometry and Fault Rocks}

In the mapped area the OLL is represented by several outcrops of 5 to $15 \mathrm{~m}$ thick foliated cataclasites (Fig. 4a), aligned with good alongstrike continuity to form a roughly N-S trending ridge (Fig. 3). The foliated cataclasites (Fig. 4a and b) originated from the brittle dismemberment of peridotite, gabbro, and granite blocks and Palombini Shale from the CC footwall (EL). The foliated cataclasites are associated with $\mathrm{m}$-thick slices of dark green cataclastic serpentinites, which crop out discontinuously aligned along the shear zone and can be followed at the scale of the map along the same N-S trending ridge (Fig. 3).

The cataclasites display a crude mesoscopic layering defined by the alternation of $\mathrm{mm}$ - to $\mathrm{cm}$-thick dark grey and green anastomosing bands (Figs. 5a and 5b) with, and sharp thickness reduction along their length. The dark grey bands show a fine-grained, homogenous granular texture, the green ones are matrix-dominated breccia where mmto $\mathrm{cm}$-size angular fragments of serpentinites, limestones and gabbros are floating in a foliated fine-grained matrix. Foliation surfaces dip toward the SW, with a strike ranging N030/N040 to N080/N090, as a result of deformation by NW-SE trending folds with gently dipping axial plane (Fig. 4c) that is visible also at map-scale as SW-facing open folds (Fig. 3). The foliated cataclasites show an internal deformation by open to close folds with E-W trending axes that does not affect the hanging wall rocks (Fig. 1): in the NW-SE striking and SW dipping foliated cataclasites, the facing of these folds indicate a top-to-the-NE sense of shear. The top of the cataclasites is not visible in the field, whereas the lower boundary of the shear zone is exposed in two outcrops (Figs. 5a and 5c) as a sharp surface where the cataclastic rocks overlie the shales and calcilutites from the $\mathrm{CC}$.

The fault core features well-developed S-C structures showing a sense of shear toward the eastern sectors (Fig. $5 \mathrm{c}$ ). The foliation surfaces bear two sets of slikenlines, one down dip and one oblique with respect to the surfaces, and mutually crosscutting (Fig. 4c). When plotted on a stereonet based on the shear sense indicators, the striae orientation clusters on two sets, one showing a thrust-type orientation of the stress, and another with a strike-slip stress field (Fig. 4c).

The crosscutting relationships among the axial planes reconstructed in the IL (Fig. 3) indicate that the traces of the axial planes of the D2a folds in the IL subunits are cut by the OLL, that is in turn deformed by the $\mathrm{D} 3$ folds.

At micro-scale (Fig. 6a), the foliated cataclasites are characterized by elongated, angular to sub-rounded clasts of serpentinite, derived from the footwall $\mathrm{CC}$, and subordinately calcite vein fragments, and calcilutites (belonging to the Palombini Shale from hanging wall and footwall). Serpentinite clasts are generally asymmetric with $\delta$-type
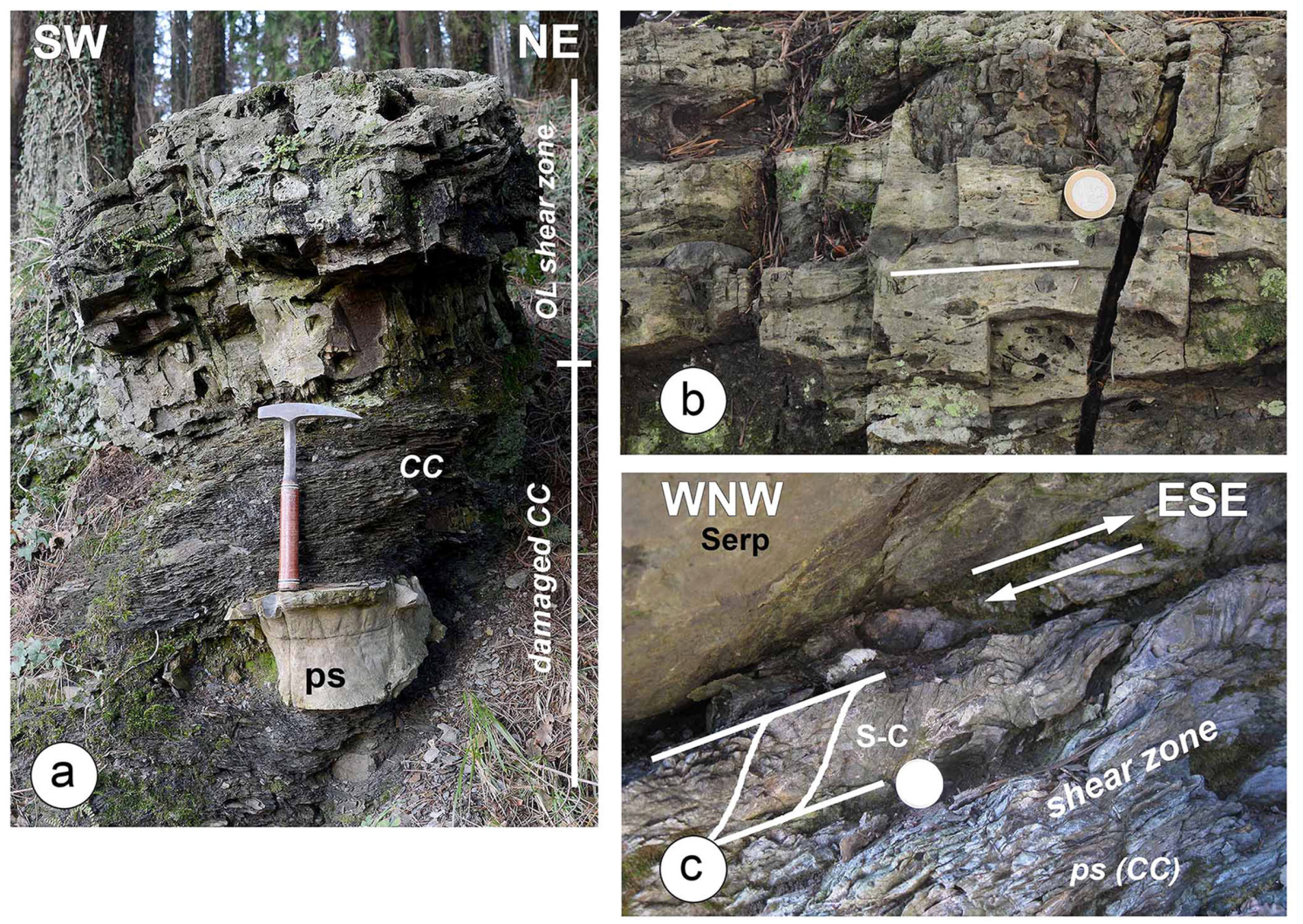

Figure 5. Map-scale features of the Ottone-Levanto line exposures. a) foliated cataclasites on top of the CC of the footwall; b) close-up of the foliated cataclasites, with foliation marked by alternation of bands with different colors (mimicked by white line), and alignment of cm-to dmsize blocks. "Vacuolar" appearance of the breccia is due to partial corrosion of carbonate fragments; c) the core of the shear zone features $S$-C brittle structures in the shales. 

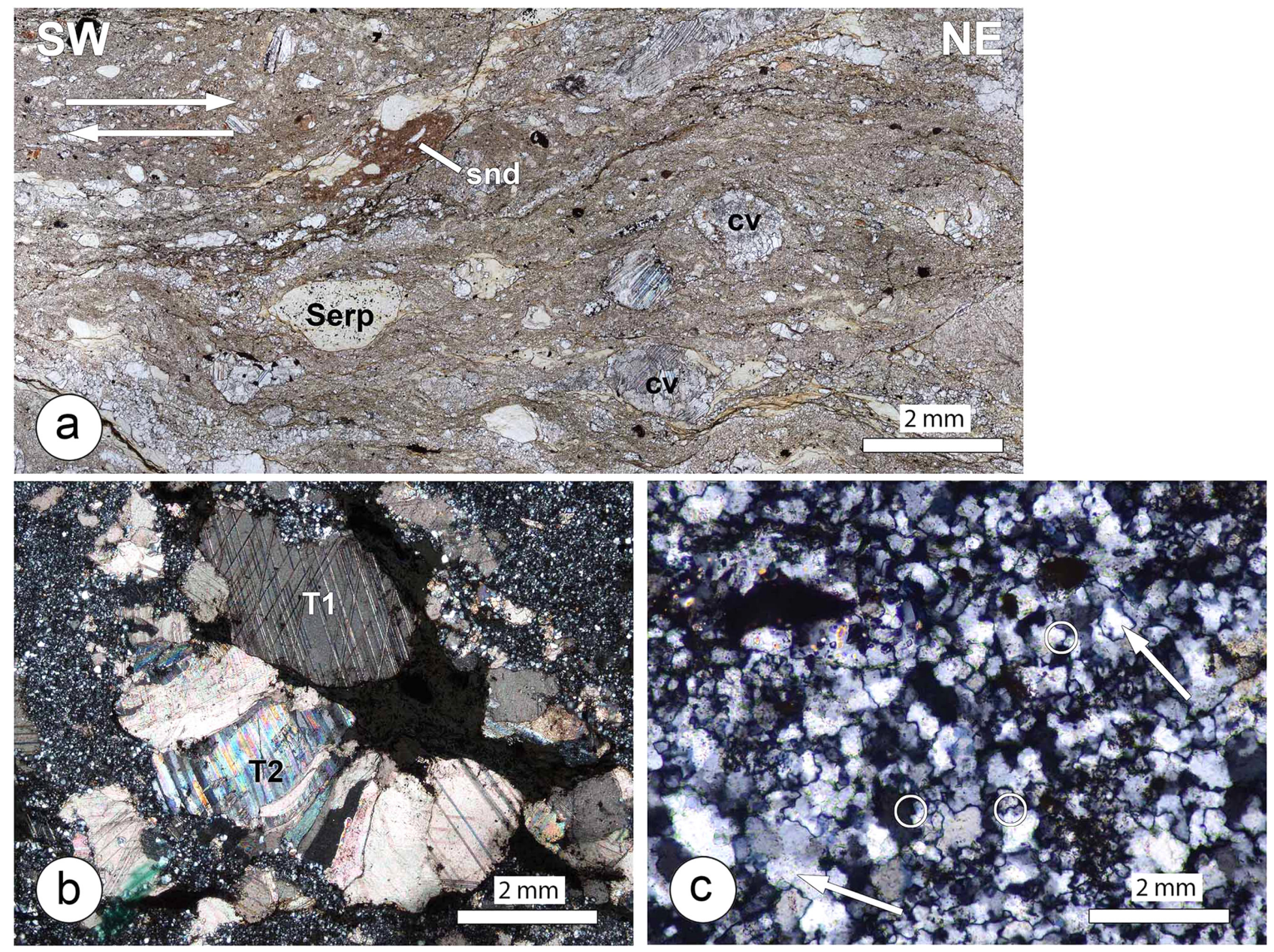

Figure 6. Foliated cataclasite at micro-scale. a) general view of the foliated cataclasites, with mm- to sub mm-scale fragments in a foliated fine matrix. Foliation is marked by pressure solution seams and phyllosilicate preferred alignment; b) two main types of calcite twin morphologies have been recognized in the cataclasites: type-1 (T1) thin and straight twins, and type-2 (T2) tabular, thick twins; c) microcrystalline quartz in granoblastic layers show undulose extinction (white arrows), and interlobate contacts (white circles).

shapes, with asymmetry being evidenced by pressure shadows at clasts edges defined by re-crystallization of micro-crystalline quartz. In oriented samples, the clasts asymmetry is indicative of a sense of shear toward the eastern sectors. Calcite in the clasts (Fig. 6b) is characterized by thin and thick, regular straight twins, ascribable to the Type I and II twin morphology classes of Ferrill et al., (2004). The foliation is a millimeter-scale alternation of cholite-rich layers and layers dominated by quartz with subordinate microcrystalline serpentine and calcite (Fig. 6a). Chlorite also occurs as an alteration product of the serpentinite clasts, whereas calcite is also found in veins, derived from alteration and fracturing of the serpentinite. Quartz is dominantly affected by intracrystalline deformation (mainly undulose exctintion), but commonly shows evidence of grain boundary migration and dynamic recrystallization (Fig. 6c).

\section{Discussion}

\section{Fault zone Evolution in the Regional Apenninic Context}

The field data collected in the Sturla valley provide a more detailed field- and micro-scale definition of the fault rocks marking the OLL and of the deformation processes active during shear zone development. We can use these data to make important assumptions on the age and the kinematics of this line.

The OLL in the investigated area is a 10 to $15 \mathrm{~m}$ thick localized shear zone consisting of carbonate rocks- and serpentinites-bearing foliated cataclasites that formed at the expenses of the Palombini Shale and of the chaotic lithologies of the CC. The sub-rounded to angular shape of the clasts, and their large grain size range, the characteristics of the foliation, the formation of pressure shadows and the re-crystallization of microcrystalline phases, suggest that cataclastic flow was the dominant mechanism, in the shallow brittle-ductile transition regime. Deformation in the calcite develops twin morphologies classifiable as of type I and II of Ferrill et al., (2004), that in the authors' estimates are indicative of temperature of deformation between $150^{\circ}$ and $300^{\circ} \mathrm{C}$. Quartz deforms essentially by intracrystalline deformation, but shows also evidences of dynamic recrystallization, then suggesting very low-grade to low-grade conditions of deformations with temperature around $300^{\circ} \mathrm{C}$.

In the foliated cataclasites, the foliation surfaces bear both downand parallelel-dip slickenlines mutually crosscutting each other (Fig. 4). 
In addition, the foliation surfaces are deformed by intrafoliar folds with E-W striking axes. These features indicate a deformation involving components of contraction with top-to-the-NE thrusting and contemporaneous top-to-the-SW sinistral shearing and dip-slip shearing (Fig. 4d). Similar, broadly contemporaneous structures, indicative of highly heterogeneous, structural patterns, have been mathematically defined and modelled as inclined transpression zones by Jones et al., (2004).

Although the study area lacks any clear direct indication about the age of line development, assumptions can be made on the base of geological evidences at map-scale (Figs. 3 and 7). The lower time limit is represented by the youngest deposits of the successions cut by the OLL in its northern segment, that are represented by the Middle Eocene deposits of the Cassio Unit (Marroni et al., 2001; Mosca et al., 2010). In the Magra and Vara valleys, east of the city of La Spezia, the OLL is cut by the basal thrust of the Ligurian Units (Monteforti and Raggi, 1975, see Fig. 7), indicating an age for the OLL not younger than Late Oligocene-Early Miocene, i.e. the age of the thrusting of the Ligurian Units over the Subligurian and Tuscan Units (Fig. 7). In addition, several field mapping of its northernmost segment (Fig. 1) indicate that the main displacement of the OLL is sealed by the Early Oligocene deposits of the Tertiary Piemontese basin (Marroni et al., 2010).

Thus, the OLL activity seems to be confined in the Late EoceneEarly Oligocene, according to Elter and Marroni (1991), Marroni and Treves (1998) and Mosca et al., (2010). This time interval for the activity of the OLL excludes any time correlation with the VVL, along which the transpressional tectonics is restricted to Late Oligocene-Late Miocene time span (Chattian to Tortonian; Festa et al., 2015).

\section{Geodynamic Significance of the Ottone-Levanto Line}

We propose an interpretation of the OLL as a sinistral traspressional shear zone developed during the Late Eocene-Early Oligocene (Fig. 8). The northern sector of the Alpine-Apennine system at this time has been depicted by Marroni et al., (2017) as an ENE-WSW double verging collisional belt, built up after the complete subduction of the oceanic lithosphere (Fig. 7). Here, at the Eocene-Oligocene boundary, the continental crust was largely involved in the compressive deformation on the Europe side of this collisional belt (Corte Unit of Alpine Corsica, Briançonnais Units of Western Alps), and would be shortly after also along the Adria side (Massa and Apuane Units of Northern Apennine) of the orogen (Molli et al., 2010). Conversely, the Adria side in the southernmost areas of the Alpine-Apennine system still featured the occurrence of oceanic lithosphere and/or large areas of ocean-continent transition during Eocene/Oligocene (Marroni et al., 2017).

This Early Oligocene articulated scenario was further complicated by the northwestward indentation of the Adria plate, associated with anticlockwise rotation (Faccenna et al., 2004). The contrasting effects of these two processes led to strain partitioning and consequent development of complex, strike-slip boundaries (e.g. Mosca et al., 2010). Widespread exhumation of high- and ultra high-pressure metamorphic units in various sectors of the Alps (e.g. Malusà et al., 2015; Fox et al., 2016) also occurred in Early Oligocene.

The Alpine-Apennine collisional belt evolution during Oligocene was therefore characterized by exhumation coeval with the nucleation and growth of strike-slip fault systems. According to Seyferth and Henk (2004), convergence during the early stages of continental collision can be largely compensated by orogen-parallel extension and lateral extrusion, instead of crustal thickening. According to this model, Rosenberg et al., (2017) proposed an Oligo-Miocene kinematics for the Eastern Alps in which the large amount of north-south shortening in the western part of the Eastern Alps, due to Adria indentation, was accommodated by a combination of lateral extrusion through conjugate strike-slip faults, and orogen-parallel extension. We can imagine a similar scenario for the main strike-slip faults dissecting the Alpine belt, the northernmost sector of the Northern Apennines, and Alpine Corsica (Fig. 8): the Sestri-Voltaggio line (dextral strike-slip; Mosca et al., 2010), the Central Corsica Shear Zone (sinistral strike-slip fault; Lacombe and Jolivet, 2005), that Mosca et al., (2010) considers as connected with the Periadriatic Fault (dextral strike-slip). We propose here that the described OLL can well fit in this picture (Fig. 8) as part of a system of strike slip faults dismembering the Alpine-Apennine system during collisional tectonics.

To better picture the primary attitude of the strike slip system prior to the Corsica-Sardinia and Northern Apennine microplate rotation, we use the paleomagnetic data of Maffione et al., (2008), which indicate a Late Oligocene-Early Miocene CCW rotation of both SardiniaCorsica block and the Western Alps of about $50^{\circ}$ with respect to Africa. In addition, the Ligurian Units of Northern Apennine rotated $\mathrm{CCW}$ of

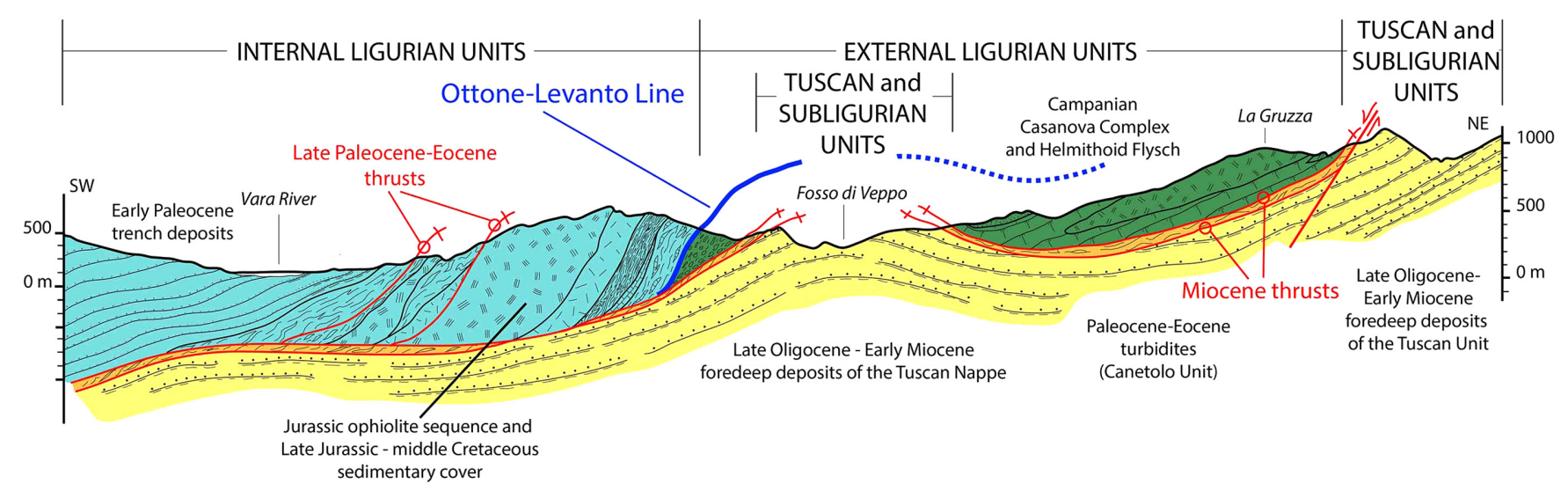

Figure 7. Geological section across the Magra and Vara valleys (modified after Monteforti and Raggi, 1975), showing the geometrical relationships between IL and EL with the Tuscan and Subligurian Units. 


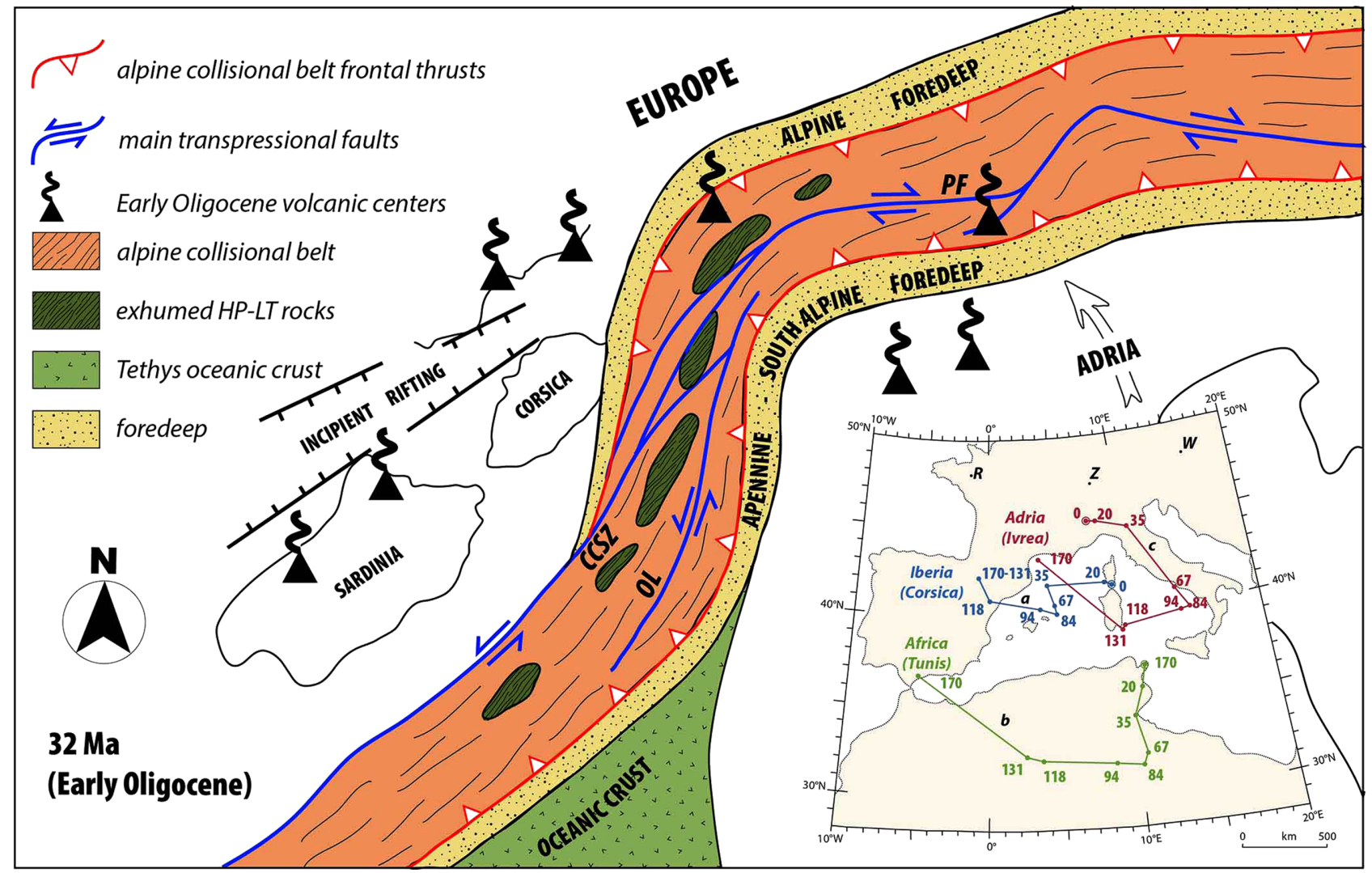

Figure 8. Schematic reconstruction of the Alps-Apennines collisional system at $32 \mathrm{Ma}$, showing the complex transpressive tectonics, aided by a system of conjugate tectonic lines: the Central Corsica Shear Zone (CCSZ), the Pusteria Fault/Insubric Line (PF) and the Ottone-Levanto Line (OL). In the inset, the motion paths of three points, a to c, located on tectonic plates, modified from Handy et al., (2010). Scale shows linear distances for centre of map and is valid at the map edges to within $0.5 \mathrm{~mm}(6.8 \mathrm{~km})$. Dotted lines = present day coastlines.

$25^{\circ}$ during Late Oligocene-Early Miocene, plus another $20^{\circ}-30^{\circ} \mathrm{CCW}$ during Pliocene time. After retro-deforming the system from these rotations, both the OLL and Central Corsica Shear Zone lines change their orientation from NNW-SSE to NNE-SSW, whereas the SestriVoltaggio line changes its orientation from N-S to NW-SE, depicting a conjugate system of faults where the dextral strike-slip Sestri-Voltaggio line, the sinistral strike-slip OLL and Central Corsica Shear Zone are coexisting (Fig. 8).

Post-orogenic intense vertical movements from subsidence to exhumation (i.e. in a 30-20 Ma time interval) has been described in the Northern Apennine (e.g. Festa et al., 2015) and in the Corsica Island (e.g. Fellin et al., 2005). In our interpretation, these vertical movements can be viewed as a consequence of the continuation, during the entire Oligocene, of the described transpressional tectonic regime.

Subsequently, these lines were progressively de-activated, with the strike slip system migrating eastward, by the activation of new faults or change of kinematics of pre-existing faults, such detected for the VVL (Festa et al., 2015).

\section{Acknowledgments}

This research was supported by funds ATENEO grant by Pisa University, and by C.N.R (Istituto di Geoscienze e Georisorse, Unità Operativa di Pisa).

\section{References}

Castellarin, A., 2001, Alps-Apennines and Po Plain-frontal Apennines relationships. In: Vai, F., and Martini, I. P. (Eds), Anatomy of an Orogen. The Apennines and adjacent Mediterranean basins, Kluwer Academic Publishers, the Netherlands, pp. 177-195.

Cerrina Feroni, A., Ottria, G., and Ellero, A., 2004, The Northern Apennine, Italy: geological structure and transpressive evolution: Memorie della Società Geologica Italiana, Special volume of International Geological Conference 32 Florence-2004, pp. 14-32.

Crispini, L., and Capponi, G., 2001, Tectonic evolution of the Voltri Group and Sestri Voltaggio Zone (southern limit of the NW Alps): a review. Ofioliti, v. 26, pp. 161-164.

Delvaux, D., and Sperner, B., 2003, Stress tensor inversion from fault kinematic indicators and focal mechanism data: the TENSOR program. Geological Society, London, Special Publications, v. 212, pp. 75-100.

Di Biase, D., Marroni, M., and Pandolfi, L., 1997, Age of the deformation phases in the Internal Liguride Units: evidences from Early Oligocene conglomerates of Tertiary Piemontese Basin Northern Apennine, Italy. Ofioliti, v. 22, pp. 231-238.

Doglioni, C., 1991. A proposal for the kinematic modelling of W·dipping subductions possible applications to the Tyrrhenian-Apennines system. Terra Nova, 3(4), 423-434.

Elter P., Marroni, M., and Pandolfi, L., 2010, Foglio 214 "Bargagli” della Carta Geologica d'Italia in scala 1:50.000, Istituto Superiore per la Protezione e Ricerca Ambientale ISPRA http://www.isprambiente.gov.it/ MEDIA/carg/214_BARGAGLI/Foglio.html. 
Elter P., Marroni, M., Molli, G., and Pandolfi, L., 1991, Caratteristiche stratigrafiche del Complesso di M.Penna/Casanova Val Trebbia, Appennino Settentrionale. Atti Ticinensi di Scienze della Terra, v. 34, pp. 97-106.

Elter, P., and Marroni, M., 1991, Le Unità Liguri dell'Appennino Settentrionale: sintesi dei dati e nuove interpretazioni: Memorie Descrittive della Carta Geologica d'Italia, v. 44, p. 121-138.

Elter, P., and Pertusati, P.C., 1973, Considerazioni sul limite Alpi- Appennino e sulle relazioni con l'arco delle Alpi Occidentali. Memorie della Società Geologica Italiana, v. 12, pp. 359-375.

Elter, P., Catanzariti, R., Ghiselli, F., Marroni, M., Molli, G., Ottria, G., and Pandolfi L., 1999, L'unità Aveto (Appennino Settentrionale): caratteristiche litostratigrafiche, biostratigrafia, petrografia delle areniti ed assetto strutturale. Boll. Soc. Geol. It, v. 118, pp. 41-64.

Faccenna, C., Piromallo, C., Crespo-Blanc, A., Jolivet, L., and Rossetti, F., 2004, Lateral slab deformation and the origin of the western Mediterranean arcs. Tectonics, v. 23, doi:10.1029/2002TC001488.

Federico, L., Capponi, G., Crispini, L., Scambelluri, M., and Villa, I. M., 2005, 39Ar/40Ar dating of high-pressure rocks from the Ligurian Alps: evidence for a continuous subduction-exhumation cycle. Earth and Planetary Science Letters, v. 240(3-4), pp. 668-680.

Fellin, M.G., Zattin, M., Picotti, V., Reiners, P.W., and Nicolescu, S., 2005, Relief evolution in northern Corsica western Mediterranean: constraints on uplift and erosion on long-term and short-term timescales. Journal of Geophysical Research, v. 110, doi:10.1029/2004JF000167.

Ferrill, D.A., Morris, A.P., Evans, M.A., Burkhard, M., Groshong, R.H., and Onasch, C.M., 2004, Calcite twin morphology: a low temperature deformation geothermomenter. Journal of Structural Geology, v. 26, pp. 1521-1529.

Festa, A., Fioraso, G., Bissacca, E., and Petrizzo, M.R., 2015, Geology of the Villalvernia - Varzi Line Between Scrivia and Curone valleys NW Italy. Journal of Maps, v. 11, pp. 39-55.

Fox, M., Herman, F., Willett, S. D., and Schmid, S. M., 2016, The exhumation history of the European Alps inferred from linear inversion of thermochronometric data. American Journal of Science, v. 316, pp. 505-541.

Handy, M. R., Schmid, S. M., Bousquet, R., Kissling, E., \& Bernoulli, D., 2010, Reconciling plate-tectonic reconstructions of Alpine Tethys with the geological-geophysical record of spreading and subduction in the Alps. Earth-Science Reviews, v. 102, pp. 121-158.

Jones, R.R., Holdsworth R.E., Clegg, P., Mccaffrey, K.J.W, and Tavarnelli, E., 2004, Inclined transpression. Journal of Structural Geology, v. 26, pp. 1531-1548.

Lacombe, O., and Jolivet, L., 2005, Structural and kinematic relationships between Corsica and the Pyrenees-Provence domain at the time of the Pyrenean orogeny: Tectonics, v. 24, doi: 10.1029/2004TC001673.

Laubscher, H.P., Biella G.C., Cassinis R., Gelati R., Lozej A., Scarascia S., and Tabacco I. 1992, The collisional knot in Liguria. International Journal of Earth Sciences (Geologische Rundschau), v. 81, pp. 275289 .

Leoni, L., Marroni M., Sartori F., and Tamponi M., 1996, The grade of metamorphism in the metapelites of the Internal Ligurid Units Northern Apennines, Italy: European Journal of Mineralogy, v. 8, pp. 35-50.

Maffione, M., Speranza F., Faccenna C., Cascella A., Vignaroli G., and Sagnotti L. 2008, A synchronous Alpine and Corsica-Sardinia rotation. Journal of Geophysical Research, v. 113, B03104, doi:10.1029/ 2007JB005214

Malavieille, J., Molli, G., Genti, M., Dominguez, S., Beyssac, O., Taboada, A., Vitale-Brovarone, A., Lu, C.-Y., and Chen, C.-T., 2016, Formation of ophiolite-bearing tectono-sedimentary mélanges in accretionary wedges by gravity driven submarine erosion: Insights from analog models and case studies. Journal of Geodynamics, v. 100, pp. 87-103.

Malusà, M.G., Faccenna, C., Baldwin, S.L., Fitzgerald, P.G., Rossetti, F., Balestrieri, M.L., Danišík, M., Ellero, A., Ottria, G. and Piromallo, C., 2015, Contrasting styles of UHP rock exhumation along the Cenozoic Adria-Europe plate boundary Western Alps, Calabria, Corsica. Geochemistry, Geophysics, Geosystems, v. 166, pp. 1786-1824.

Marroni, M., and Pandolfi, L., 2007, The architecture of the Jurassic Ligure-Piemontese oceanic basin: tentative reconstruction along the Northern Apennine - Alpine Corsica transect. International Journal of Earth Sciences, v. 96, pp. 1059-1078.

Marroni, M., and Pandolfi, L., 1996. The deformation history of an accreted ophiolite sequence: The internal Liguride units (Northern Apennines, Italy). Geodinamica Acta, 9(1), 13-29.

Marroni, M., and Treves, B., 1998, Hidden Terranes in the northern Apennines, Italy: a record of Late Cretaceous-Oligocene transpressional tectonics. Journal of Geology, v. 106, pp. 149-162.

Marroni, M., Pandolfi, L., and Meneghini, F., 2004, From accretion to exhumation in a fossil accretionary wedge: a case history from Gottero Unit Northern Apennines, Italy. Geodinamica Acta, v. 17, pp. 41-53.

Marroni M., Meneghini F., and Pandolfi L., 2017. A revised subduction inception model to explain the Late Cretaceous, double vergent orogen in the pre-collisional Western Tethys: evidence from the Northern Apennines. Tectonics, v. 36, doi: 10.1002/2017TC004627.

Marroni, M., Molli, G., Ottria, G., and Pandolfi, L., 2001, Tectono-sedimentary evolution of the External Liguride Units Nothern Apennines, Italy: insights in the pre-collisional history of a fossil ocean-continent transition zone. Geodinamica Acta, v. 14, pp. 307-320.

Masini, M., Bulnes, M., and Poblet, J., 2010, Cross-section restoration: A tool to simulate deformation. Application to a fault-propagation fold from the Cantabrian fold and thrust belt, NW Iberian Peninsula. Journal of Structural Geology, v. 32(2), pp. 172-183.

Meneghini, F., Marroni, M., Moore, J.C., Pandolfi, L., and Rowe, C.D., 2009, The process of underplating in the geologic record: structural diversity between the Franciscan Complex California, the Kodiak Complex Alaska and the Internal Ligurian Units Italy. Geological Journal, v. 44, pp. 126-152, doi: 10.1002/gj.1144.

Molli, G., Crispini, L., Malusà, M., Mosca, P., Piana, F., and Federico, L., 2010, Geology of the Western Alps-Northern Apennine junction area: a regional review. In: M. Beltrando et al. (Eds.), The Geology of Italy, Journal of the Virtual Explorer, v. 36, paper 9.

Monteforti, B., and Raggi, G., 1975, Per la geologia dell'entroterra di La Spezia tra Sarzana e Zignago. Bollettino della Società Geologica Italiana, v. 94, pp. 927-943.

Mosca, P, Polino, R., Rogledi, S., and Rossi, M., 2010, New data for the kinematic interpretation of the Alps-Apennines junction Northwestern Italy. International Journal of Earth Sciences, v. 99, pp. 833-849.

Rosenberg, C.L., Schneider, S., Scharf, A., Bertrand, A., Hammerschmidt, K., Rabaute, A. and Brun, J.P., 2017, Relating collisional kinematics to exhumation processes in the Eastern Alps. Earth-Science Reviews, v. 176, pp. 311-344.

Saccani, E., Dilek, Y., Marroni, M., and Pandolfi, L., 2015, Continental margin ophiolites of Neotethys: remnants of ancient Ocean-Continent Transition Zone OCTZ Lithosphere and their geochemistry, mantle sources and melt evolution patterns. Episodes, v. 384, pp. 230-249.

Seyferth, M. and Henk, A., 2004, Syn-convergent exhumation and lateral extrusion in continental collision zones-Insights from three-dimensional numerical models. Tectonophysics, v. 3821, pp. 1-29.

Treves, B., 1984, Orogenic belts as accretionary prisms: The example of the northern Apennines. Ofioliti, v. 9, pp. 577-618. 


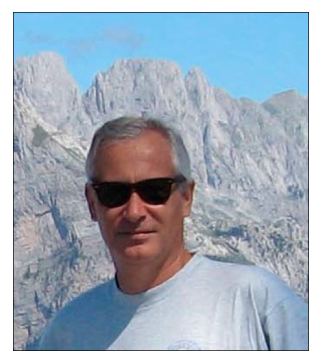

Michele Marroni: HIS research activity is focused on the structural and tectonic evolution of oceanic and continental units involved in subduction, obduction and continental collision processes. This research activity has been adressed to different geodynamic settings in several european and extra-european areas, from Italy (Northern Apennines and Western Alps) to France (Corsica and Western Alps), Albania, Romania, former Yugoslavia, Greece, Iran, Turkey, Venezuela, Guatemala and Santo Domingo.

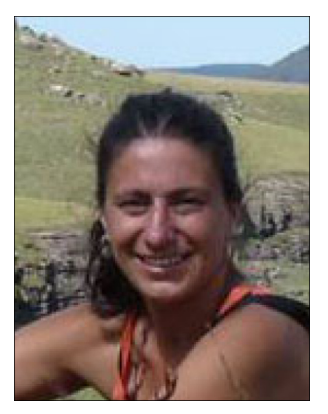

Francesca Meneghini: HER research activity focused on the tectonic and structural subduction zone processes active during mid- to shallowlevels of accretion, and on the associated fluid-induced deformation and fluid-rock interaction. Of particular interest is to decipher the role of overpressured fluid migration in controlling the mechanical state of plate boundary thrusts and their slip behavior. The studied on-land examples span from the Northern Apennines of Italy, the Franciscan Complex of California and the Kodiak Accretionary Complex of Alaska, back in time to the Neo-Proterozoic Pan-African belts (Saldania and Damara belts of South Africa and Namibia, respectively).

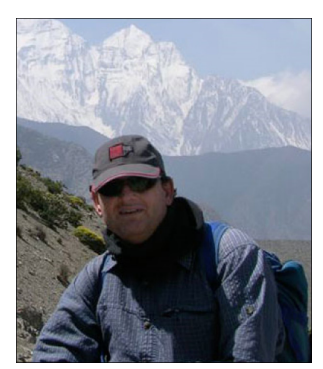

Luca Pandolfi: HIS research activity has been mainly focused on stratigraphy and structural-tectonic evolution of ophiolites and its sedimentary cover, with special attention to the relationships between tectonics and sedimentation. The research has been developed in different areas, in particular on the ophiolites of Northern Apennines, Alpine Corsica, Venezuela, Serbia, Guatemala, Santo Domingo, Romania, Iran, Turkey, Former Yugoslavia, Albania and Greece. 